\title{
The Use of Celebrity Influence Model in Pandemic Communication: Examining Micro- Celebrities' Instagram Accounts
}

Özlem Alikılıç

Yașar University Faculty of Communication

https:/lorcid.org/0000-0001-6311-2622

ozlem.alikilic@yasar.edu.tr

\author{
Asuman Özer \\ Yașar University Faculty of Communication \\ https:/lorcid.org/0000-0001-6597-6563 \\ asuman.ozer@yasar.edu.tr
}

Öz

Communicating during a pandemic is as difficult as fighting it. Social media influencers have become role models in the pandemic due to the guiding nature of social media. The aim of this study is to analyze how micro-celebrities on Instagram, one of the most preferred social networks in Turkey, carry out their COVID-19-related content and how they communicate through Instagram during the pandemic. The conceptual framework of based on "Celebrity Influence Model", the top 10 micro-celebrities posts were examined. Results show that $68.4 \%$ of the posts are related to COVID-19; their sponsored posts were decreased; they mostly preferred a "humorous" tone in their messages, they preferred their posts as "indoors", and the most shared topic is "lifestyle". "Fun" is the most used value by micro-influencers. The primary role they assumed was "entertainer". It has been observed that micro-celebrities aim to inform, warn, direct and even develop positive behavioral changes by raising awareness on issues, such as staying at home, complying with social distance rules and wearing masks.

Keywords: pandemic communication, celebrity influence model, COVID-19, Instagram, micro-celebrity

Received: 15.02.2021 - Accepted: 15.11.2021

http://ilefdergisi.ankara.edu.tr

ilef dergisi • () 2021 - Özel Sayı • güz/autumn: 149-178

Araștırma Makalesi - DOl: 10.24955/ilef.1037992 


\section{Ünlü Etkisi Kullanımı}

Çerçevesinde Pandemi Iletișimi:

Instagram Mikro-Ünlüleri Üzerine bir inceleme

\section{Özlem Alikılıç}

Yașar Üniversitesi Illetișim Fakültesi

https://orcid.org/0000-0001-6311-2622

ozlem.alikilic@yasar.edu.tr
Asuman Özer

Yașar Üniversitesi iletișim Fakültesi

https://orcid.org/0000-0001-6597-6563

asuman.ozer@yasar.edu.tr

Abstract

Pandemi sırasında iletișim kurmak pandemi ile savașmak kadar zordur. Sosyal medya fenomenleri sahip oldukları yol gösterici doğa sayesinde pandemide rol modeller hâline gelmiștir. Bu çalıșmada amaç, Türkiye'de en çok tercih edilen sosyal ağlardan biri olan Instagram'daki mikro-ünlülerin salgın döneminde COVID-19'la ilgili içeriklerini, pandemide iletișimlerini Instagram üzerinden nasıl gerçekleștirdiklerini analiz etmektir. Çalıșmanın kavramsal çerçevesi, "Ünlü Etkisi Modeli" üzerinden geliștirilmiș ve Instagram üzerinde (Türkiye'de 2019 yllında etki gücü skoruna göre) ilk on sıraya yerleșmiș mikro-ünlülerin pandemi dönemindeki paylașımları analiz edilmiștir. Bulgulara göre; mikro-ünlülerin karantina döneminde yaptıkları paylașımların \%68,4'ünün COVID-19 ile ilgili olduğu; sponsorlu gönderilerin azaldığı, pandemide kullandıkları mesaj tonunun en çok mizah olduğu; karantina döneminde paylașılan gönderilerin çoğunun iç mekânda paylașıldı̆̆ı, en çok "hayat tarzı" ile ilgili paylașım yapıldı̆̆ı; mikro-ünlülerin bu dönemde takipçilerine en çok "eğlenme" değerini sundukları; üstlendikleri temel rolün en çok eğlendirme rolü olduğu görülmüștür. Ilaveten, mikro-ünlülerin evde kalma, sosyal mesafe kurallarına uyma, maske takma gibi konularda farkındalık yaratarak takipçilerini bilgilendirmeyi, uyarmayı, yönlendirmeyi ve hatta olumlu davranıș değișiklikleri geliștirmeyi amaçladıkları gözlemlenmiștir.

Anahtar Kelimeler: Pandemi iletișimi, ünlü etkisi modeli, COVID-19, Instagram, mikro-ünlüler

Makale geliș tarihi: 15.02.2021 • Makale kabul tarihi: 15.11.2021

http://ilefdergisi.ankara.edu.tr

ilef dergisi • ( 2021 - Özel Sayı • güz/autumn: 149-178

Research Article • DOI: 10.24955/ilef.1037992 


\section{Introduction}

In 2020, the world experienced a new pandemic called COVID-19; the case was firstly seen in China, Wuhan, on the 31st of December, 2019 (WHO 2020) and step by step spread to the whole world (Statista 2020a). Turkey is one of the countries, which was affected by COVID- 19. Once the first case was seen on the 11th of March, 2020 (McKernan 2020), Turkey tightened the precautions and closed the schools, universities, and cancelled all sports competitions. In addition to that, all restaurants, shopping malls, cafes, concerts, wedding halls, hairdressers, gyms, and theatres were closed, and also Presidency of Religious Affairs published that all Friday prayers were banned everywhere in Turkey (Daily Sabah 2020). It can be concluded that COVID-19 has changed daily life economically, socially and has affected life in terms of health (Haleem et al. 2018, 78). The effects of the COVID-19 crisis have gone beyond being a health problem and dramatically transformed individuals' social and economic lives (Yavuz 2020, 190).

One of the areas that are particularly affected by the pandemic in social life is communication. After the start of the pandemic process, almost all communication habits have changed. According to Fuchs (2020, 384), people spend their time in social isolation in their homes, and they have to prefer vir- 
tual communication through digital technologies instead of physical communication. Most of the face-to-face communication activities had to transform into digital communication. For instance, people have started organizing parties, and meetings digitally during COVID-19 pandemic (Wen 2020). Information exchange through peer to peer communication was restricted during the pandemic process, and information flows have started to be done through mobile phones, video conferences or e-mails (Marra et. al. 2020, 1). According to Statista (2020b), individuals in the USA have used a social network to communicate on pandemic days. $25 \%$ of respondents of the survey have used digital networks for joining a work meeting. Also, $76 \%$ of respondents have communicated with their friends and family members through e-mail or message service, and $70 \%$ of respondents have used social media for getting information about COVID-19.

In pandemic days, increasing social isolation and spending more time at home has led to an increase in the number of social media accounts gradually. This situation makes social media an alternative communication tool (Kırık and Özkoçak 2020, 145) for retrieving information. According to Adba Analytics (2020) report, the pandemic has increased panic, and that is why social media users have found it appropriate to retrieve accurate and current information from the official social media accounts of various organizations, such as the World Health Organization. According to the same report, between January 21 and March 21 2020, social media users globally shared more than 275 million content only about COVID-19. Furthermore, social media have played a significant role in individuals' adaptation process to the pandemic. For instance, Whatsapp has created a COVID-19 information data hub. In addition, Instagram has launched the \#stayhome hashtag for stories, and also Twitter has started to ban each tweet that was spreading misinformation about COVID-19 (Reitere 2020).

Besides providing information, users have made their time more enjoyable on social media by following social media influencers (Yaylagül 2017, 220). Social media influencers have adapted themselves to this enjoyment, too. These influencers gain their popularity from their online presence and representations of themselves. Before the pandemic, they had shared content, especially on the outside, however, within COVID-19, they needed to stay at home and share content inside (Bishop 2020). It's true to say that since the life of influencers has changed due to the pandemic, they adopted themselves, which mainly consisted of healthy lifestyles and they gained new habits during the pandemic. 


\section{Pandemic Communication and Influencers}

Since the ending period of COVID-19 pandemic is still unknown, people have to learn how to adapt themselves into this new style. This adaptation requires seeking and adapting alternative communication tools both for the continuity of professional and social life (Abraham 2011, 1-4). One of the most significant factor in risks and crises (i.e. pandemic) is communication (Longstaff and Yang 2008). Especially pandemics, such as SARS, H1NI1 have acknowledged communication as an important tool during public information seeking (Lin et al. 2017, 282; Jones et al. 2010).

Pandemic communication is defined as the type of communication that aims to prevent the spread of misinformation about the disease and to accelerate the recovery process by providing correct forms of communication to make the public act together (Vaughan and Tinker 2009, 324). According to another definition, pandemic communication determines the communication priorities of the society and aims to interact during the outbreak through proper channels. It contains all the elements of interpersonal, intercultural and mass communication (Özpınar and Aydın 2020, 244). Pandemic communication aims to form public opinion about the pandemic and help the public retrieve correct information about the pandemic disease (Pan American Health Organization 2009).

Within the COVID-19 period, people had to stay away from their family and friends, and they had to postpone their communication habits. People had started to worry about whether they would be able to communicate normally again in the future (Ducharme 2020).

In the COVID-19 pandemic, one of the most reliable platforms of individuals were social media platforms (Limaye et al. 2020, 277). People use social media to provide emotional support during crises like this (Kırık and Özkoçak 2020). Users establish an emotional bond during pandemic with the social media influencers they know (Jin et al. 2019, 570). Influencers are defined as people who communicate with their actions and, as a result, have the power of informing and influencing followers (Dhanesh and Duthler 2019, 3).

Within the COVID-19 pandemic, a large fragment of society has gone online and followed social media influencers. According to the Social Influencer Report 2020,44\% of individuals consider what social media influencers say and do about their health. Findings also state that, with the start of COVID-19, 
influencers' total shipping interaction has exceeded 2.9 million (Suciu 2019). According to Social Bakers 2020 data, the most prominent sector in the brand collaborations of the influencers was the health sector. The health-related content produced by the influencers was $4.2 \%$ more liked and found helpful than the content they produced for other products. The same report admits that influencers have also shared content about how they spend time at home.

Gilliland (2020) says that they have encouraged their followers to be careful about social isolation, and staying at home, and have uploaded videos and photos that reflect their daily life at home (Elmacioğlu 2020). Moreover, they have tried to persuade their followers to stay at home by taking pictures interiors. For example, Naomi Davis, a lifestyle influencer based in New York, shared a post that showed how she quarantined herself at home. Food blogger Ali Maffuci shared a post about leaving the city and staying home (Lorenz 2020). Turkish influencer Danla Biliç, a female influencer with the highest number of followers in Turkey (Boom Social 2021), shared many posts on Instagram about her domestic lifestyle during the quarantine days. Similarly, Burak Özdemir, a top-ranking male influencer, shared posts about cooking bread at home, and he kept giving different recipes to his followers (Boom Social 2021).

The influencers with the power of interaction (Saritaş 2018, 66) had the opportunity to interact more due to the increase in the utilization of digital platforms in quarantine days. According to an analysis of United Ad 2020 in Turkey, the interactions of influencers' Instagram posts have increased $4.5 \%$ in March than February. According to the same report, it was determined that the rate of content produced about "staying at home" in March was higher than in February. The report also showed that, although the interaction power of influencers and their potential for content production seems to have increased with the COVID-19, the existence of influencers has been felt for a long time since digitalization has begun. Today influencers have entered all areas of life, have increased their popularity. The popularity of the influencers caused them to be segmented and categorized into different types.

\section{Categorizing Influencers}

With the increasing popularity of influencers, they are called the new celebrities of the digital world (Alev and Ünlü 2016,41). This so new-called status has caused influencers to be mentioned as "micro-celebrities" in the literature (Lin et al. 2018,435). A classification of social media influencers using differ- 
ent memes as "micro-influencer", "macro-influencer", and "mega-influencer" have recently used in the literature (Kay et al. 2020, 252-253). Nano and meso influencer concepts can also be found in the literature (Boerman 2020, 199; Berne-Monero and Marzo-Navarro 2020). The classification of influencers into these memes is based on the number of followers that influencers have (Berne-Monero and Marzo-Navarro 2020, 4). However, there is no specific information on how many followers an influencer must have to be a mega, micro or macro-influencer. For instance, according to the BCU Digital 2021 report, micro-influencers are celebrities who have between 10.000 to 50.000 followers; while macro-influencers have followers between 500.000 to 1.000.000, and mega-influencers have followers over 1.000.000 Another study shows that macro-influencers must have over 100.000 to 1.000 .000 followers (Berne Monero and Marzo-Navarro 2020, 4). When an influencer has followers around 10.000 to 1.000.000, it is called "meso-influencer" (Boerman 2020, 199), and when it is less than 1.000 followers, it is called "nano influencer" (Karanikolova 2019, 13).

The number of followers is not the only criterion for the influencer classification. They are classified per their involvements, expertising of different topics, occupations and characters (Karanikolova 2019, 12). Micro-influencers have similar characteristics to their followers. This similarity provides a relationship of trust between each other. Micro-influencers inspire followers; they follow micro-influencers suggestions to learn how they succeeded (Hurd 2018, 69). Even though micro-influencers have fewer followers than macroinfluencers, micro-influencers followers are more loyal (Coelho 2019, 12).

Since the followers of macro-influencers are more than micro-influencers, the target markets they reach are more prominent (Nguyen 2020, 22). Even though macro-influencers have a large number of followers, they are less specialized than micro-influencers, and they share more general topics such as a favourite car, favourite fashion style, or travel places (Christodoulaki 2018, 7-8). Like macro-influencers, mega influencers also have high numbers of followers, but their followers have low loyalty and engagement (Guruge 2018, 25; Elli 2017, 12). Mega-influencers have less influence on their followers since they are not specialists as micro-influencers about any niche topics (Borén 2020, 5). According to the report of United Ad in 2020, micro-influencers provide more effect and positive feedback than macro and mega ones (Acar 2020). This might be the reason that caused an increase in the importance of micro-influencers recently. 
All these interaction powers of influencers are similar to the effects of well-known celebrities on individuals. Because they are perceived as admiring individuals by societies. Many individuals idolize celebrities and try to resemble them (Solak 2016, 263). As a result of this idealization of influencers, many brands collaborate with influencers to benefit from their role model influence (Abidin and Ots 2016, 155).

From Turkey, Danla Biliç is one of the best examples of make-up and lifestyle influencers. She has more than 5M followers on Instagram by 2020, and she was selected as the most inspiring influencer in 2019 (Plus 2019). In 2020, she collaborated with the famous Turkish e-commerce site, "Trendyol" (Campaign Türkiye 2020) and she was selected as the digital brand face of one of the global brands Head and Shoulders in Turkey (YouTube 2021). "Celebrity Influence Model" explains how these people affect individuals (Wen 2017, 1234) and how influencers have the power to influence individuals when collaborating with brands.

\section{Celebrity Influence Model}

Fraser and Brown (2002) are the first to introduce the celebrity influence model. The celebrity influence model focuses on possible control of individuals who have affected media exposure (Brown and Fraser 2004), and it proposes three central claims: (1) People are exposed to celebrities through the media. This situation develops a one-way admirer relationship within celebrities. (2) This relationship causes individuals to identify themselves with the celebrity. (3) With this identification, different changes occur in the individuals' behaviors to resemble that celebrity. More identification with a celebrity creates greater adoption of the celebrity's behavior (Wen 2017, 1236).

The celebrity influence model is based on parasocial relationships and identification (Wen 2017, 1236). According to Brown et al. (2003, 47), parasocial relationship and identification are very similar concepts within the connection between media and viewers because participation in parasocial relationships and identification can be evaluated due to media exposure.

The mass media creates a parasocial relationship, enabling the development of imaginary face-to-face relationships between celebrities and audiences (Donald and Wohl 1956, 215). According to another definition, a parasocial relationship represents a single-sided relationship between media characters and audiences (Ballantine and Martin 2005, 197). In parasocial relationships, 
audiences are exposed to celebrities for long periods. Thus, they get a feeling that celebrities notice them (Hartmann and Goldhoorn 2011, 1106).

Within the media perspective, identification perceives oneself as equivalent to celebrity people (Cheney 1983). Therefore, identification is social influence, and it occurs when individuals adopt themselves with media characters (Fraser and Brown 2002, 187). According to Brown and Fraser $(2004,104)$, identification is more effective than parasocial relationships. Because individuals who identify themselves with the celebrity adopt celebrities' values, reliances and behaviours. Also, in the celebrity identification process, audiences are exposed to the media and adopt celebrities' lifestyles, fashion and talking style. Some audiences with a high level of admiration can identify themselves personally with celebrities.

A research conducted with Elvis Presley fans showed that Elvis fans consciously identified themselves with him, and they perceived Elvis as an artist and a husband, friend, father, and citizen (Fraser and Brown 2002). Another research about young individuals' attitudes towards cosmetic surgeries showed that college students were influenced by celebrities and developed a positive attitude towards cosmetic surgery. (Wen 2017).

There are also many studies regarding how the celebrity influence model is used in health and pandemic communication. For instance, in the 1990s, many celebrities announced that they were HIV positive. In 1995, the famous basketball player Magic Johnson's public disclosure of his HIV positive case was examined within the framework of the parasocial relationship. According to the results, individuals who felt more emotionally belonging to Magic Johnson were more concerned about HIV / AIDS. It's interesting that same research found that not every celebrity has the same power on creating awareness about diseases. The influence power of a celebrity depends on the public's identification of that celebrity (Brown and Basil 1995, 341-361).

Kosenko et al. (2016, 312-326) analyzed Angelina Jolie's genetic breast cancer (BRCA1) within the celebrity influence model. Findings reveal that, Angelina's announcement of her illness influenced many women and encouraged them to take the BRCA1 test.

\section{Methodology}

With the acceptance of the use of qualitative and quantitative researches together in social sciences, this study utilizes complementary mixed methodology combining two types of data collection; combination of quantitative and 
qualitative methods. In this quantitative methodology, descriptive analysis (Zikmund et al. 2003) and content analysis (Stemler 2001; Baltacı 2019, 377) were applied to the collected posts. The purpose of this study was to explore the micro-celebrities content related to COVID-19 in Instagram, and to analyze how they had carried out pandemic communication via social media within the framework of the celebrity influence model. The reason why Instagram selected for this study is based on the 2020 data of "We Are Social" that listed Instagram as the second most widely used social media applications in Turkey. Compared to YouTube, which ranked first, Instagram application that provides retrospective access to different types of sharing that offers instant sections, such as photographs, written texts and stories besides the video (We Are Social 2020). Also according to Marketing Hub 2019 report, Instagram is the most widely used social media platform among social media influencers marketing with a $79 \%$ rate.

The analysis was conducted between March 16, 2020 when the quarantine began and June 1, 2020 when the quarantine ended. The content uploaded during the 2,5 months quarantine period was examined. In this mixed method study, researchers collected qualitative and quantitative data concurrently (Baki and Gökçek 2012). This two-staged approach comprises texts and photographs. In the first stage, the texts (including hashtags) were read carefully, and coded. In the second stage, visual analysis was performed in order to determine how and where the influencers demonstrate themselves.

\section{Sampling}

Purposeful sampling method was used. The micro-celebrities' accounts, which ranked in the top ten according to the interaction score of CreatorDen report 2019, were selected. The interaction factor that forms the most basic structure of influencer marketing is calculated as the ratio of likes and comments to the number of followers (Hughes et al. 2009, 7). Interaction score in the CretorDen 2019 report, were calculated by giving a number between 1 and 10. According to the CreatorDen 2019 report; influencers with the most interactions are Danla Biliç (10/9.90). This ranking list is as follows: Eylül Öztürk (10/9.85), Aykut Elmas (9.82), Oğuzhan Uğur (10/9.80), Yasemin Sakallığlu (10/9.77), Şeyda Erdoğan (10/9.73), Pelin Akil (10/9.70), Duygu Özaslan (9.70), Berkcan Güven (10/9.68) and Damla Altun (10/9.65).

Interaction rate differs from the number of followers. When they are compared, micro-celebrities with a low interaction rate may have a higher number of followers. Numbers shows that aykutelmas $(5.9 \mathrm{M})$ has been the top rank. 
He is followed by danlabilic (5.7 M), yasemoz88 (4.2 M), eylulozturk (3.3 M), berkcan and oguzhanugur (2.9 M), pelinakil (2.5M), duyguozaslan (1.9 M) and damlaaltun $(551 \mathrm{~K})$. Although Aykut Elmas has got the highest number of followers, he is in third place in the interaction list.

\section{Research Questions}

Research metrics based on "Influencing is Our New Reality" (Ogilvy Agency 2020) and "The State of Influencer Marketing Report" (Launch Metrics 2020) were used. Based on these metrics, 4 main research questions were determined.

(RQ1) Did the sponsored contents of social media influencers decline during the quarantine period? If there was a decrease, in which month did this decrease occur the most?

(RQ2) How did influencers adapt COVID-19 process to their strategies?

Alatas et al.'s (2019) factors were used to explore how influencers have adapted COVID-19 process. These factors are listed respectively: 1) Use of hashtags, (2) Subjects of content (3) Type of content (4) Tone of content (5) Use of place

(RQ3) What values did influencers offer to their followers during the quarantine period?

According to the Launch Metrics 2020 report; influencers offered 5 basic values to their followers during the quarantine period. These are (1) entertainment, (2) advice, (3) social responsibility, (4) self-expression, and (5) inspiration.

(RQ4) What roles did influencers have in the quarantine period?

According to the Ogilvy report (2020), there are 4 main roles micro-celebrities play in the quarantine period. These roles are (1) entertainer, (2) informer, (3) economy booster, and (4) fundraiser.

\section{Coding and Validity}

A specific unit analysis tool was adapted from Ogilvy Agency (2020) and Launch Metrics (2020). Two coders analyzed 604 posts selected from the sample in accordance with the code list. Researchers used a coding sheet, and took detailed notes during each COVID-19 related posts of the influencers.

By comparing the data entries of all two coders, all coders came to an agreement by making the required changes in the coding of the study and entered the data in SPSS V.23 program. Krippendorff's alpha coefficient was cal- 
culated in order to test the reliability among the coders. K ALPHA value was determined as $\alpha=0,764$. This value is within the limits (Krippendorff 2011).

\section{Findings}

When the posts and stories were assessed, it was concluded that Damla Altun $(n=289)$ shared the most during the quarantine period. She was followed by seydaerdogan $(n=70)$, duyguozaslan $(n=62)$, yasemoz88 $(n=43)$, aykutelmas $(n=36)$, eylulozturk $(n=36)$, pelinakil $(n=28)$, danlabilic $(n=19)$, oguzhanugur $(\mathrm{n}=16)$ and berkcan $(\mathrm{n}=5)$.

Table 1. Number of Shares

\begin{tabular}{|l|r|r|r|r|}
\hline Names & Frequency & Percentage & \multicolumn{1}{l|}{$\begin{array}{l}\text { Valid } \\
\text { Percentage }\end{array}$} & $\begin{array}{l}\text { Cumulative } \\
\text { Percentage }\end{array}$ \\
\hline danlabilic & 19 & 3,1 & 3,1 & 3,1 \\
\hline eylulonline & 36 & 6,0 & 6,0 & 9,1 \\
\hline aykutelmas & 36 & 6,0 & 6,0 & 15,1 \\
\hline oguzhanugur_- & 16 & 2,6 & 2,6 & 17,7 \\
\hline yasemoz88 & 43 & 7,1 & 7,1 & 24,8 \\
\hline seydaerdogan & 70 & 11,6 & 11,6 & 36,4 \\
\hline pelinakil & 28 & 4,6 & 4,6 & 51,1 \\
\hline duyguozaslan & 62 & 10,3 & 10,3 & 51,3 \\
\hline berkcan & 5 &, 8 &, 8 & 100,0 \\
\hline damlaaltun & 289 & 47,8 & 47,8 & \\
\hline Total & 604 & 100,0 & 100,0 & \multicolumn{3}{|c|}{} \\
\hline
\end{tabular}

Table 2. Number of Shares by Weeks

\begin{tabular}{|l|r|r|r|r|}
\hline Weeks & Frequency & Percentage & \multicolumn{1}{l|}{$\begin{array}{l}\text { Valid } \\
\text { Percentage }\end{array}$} & $\begin{array}{l}\text { Cumulative } \\
\text { Percentage }\end{array}$ \\
\hline First Week (16-22 March) & 59 & 9,8 & 9,8 & 9,8 \\
\hline Second Week (23-29 March) & 74 & 12,3 & 12,3 & 22,0 \\
\hline Third Week (30 March 5 April) & 57 & 9,4 & 9,4 & 31,5 \\
\hline Fourth Week (6-12 April) & 58 & 9,6 & 9,6 & 41,1 \\
\hline Fifth Week (13-19 April) & 53 & 8,8 & 8,8 & 49,8 \\
\hline Sixth Week (20-26 April) & 43 & 7,1 & 7,1 & 57,0 \\
\hline Seventh Week (27 April-3 May) & 69 & 11,4 & 11,4 & 68,4 \\
\hline Eight Week (4-10 May) & 62 & 10,3 & 10,3 & 78,6 \\
\hline Ninth Week (11-17 May) & 62 & 10,3 & 10,3 & 88,9 \\
\hline Tenth (18-24 May) & 49 & 8,1 & 8,1 & 97,0 \\
\hline Eleventh Week (25-31 May) & 18 & 3,0 & 3,0 & 100,0 \\
\hline Total & 604 & 100,0 & 100,0 & \\
\hline
\end{tabular}


Results of Table 2 show that the most shared contents were made in the second week $(n=74)$ and the least shared was made in the last ( $11^{\text {th }}$ week) $(n=18)$. It can be said that the uncertainty at the beginning of the quarantine and the feeling of anxiety being replaced by the habits of the second week and the tendency to deal with the phone and internet at home caused the sharing to intensify in the second week. On the other hand, the quarantine ended on June 1, 2020, and it was previously reported in the media (CNN Turk 2020). This situation had been effective in the decline of the shares in the last week.

Table 3. Post Type Status

\begin{tabular}{|l|r|r|r|r|}
\hline Valid & Frequency & \multicolumn{2}{|l|}{ Percentage } & \multicolumn{2}{l|}{ Valid } & \multicolumn{2}{l|}{$\begin{array}{l}\text { Cumulative } \\
\text { Percentage }\end{array}$} & \multicolumn{2}{l|}{ Percentage } \\
\hline Post & 283 & 46,9 & 46,9 & 100,0 \\
\hline Story & 321 & 53,1 & 53,1 & \\
\hline Total & 604 & 100,0 & 100,0 & \\
\hline
\end{tabular}

According to findings of Table 3 showed that $53.1 \%$ of the content were in story status and $46.9 \%$ of the content remained in the post status. Since the duration of the stories on Instagram are limited to 24 hours, the stories shared during the quarantine period were accessed through the profiles' fixing panel. Findings revealed that influencers fixed their story sharing during the quarantine period under their profiles with the basic three hashtags: "Evdeyim", "karantina" "quarantine". Since only three micro-celebrities (Eylül Öztürk, Berkcan Güven and Pelin Akil) did not fix their stories, their story sharings could not be included in the analysis.

Table 4. Posts' Relation to COVID-19

\begin{tabular}{|l|c|c|c|c|}
\hline Valid & Frequency & Percentage & $\begin{array}{l}\text { Valid } \\
\text { Percentage }\end{array}$ & $\begin{array}{l}\text { Cumulative } \\
\text { Percentage }\end{array}$ \\
\hline Related to Covid-19 & 413 & 68,4 & 68,4 & 68,4 \\
\hline $\begin{array}{l}\text { Not related to } \\
\text { Covid-19 }\end{array}$ & 191 & 31,6 & 31,6 & 100,0 \\
\hline Total & 604 & 100,0 & 100,0 & \\
\hline
\end{tabular}

Findings of Table 4 showed that $68.4 \%$ of the posts were related to COVID-19 and $31.6 \%$ were not related to COVID-19. It can be concluded that influencers could not stay away from the COVID-19 agenda. 
Table 5. Status of Sponsored Posts

\begin{tabular}{|l|r|r|r|r|}
\hline Valid & \multicolumn{1}{|l|}{ Frequency } & Percentage & \multicolumn{1}{l|}{ Valid } & \multicolumn{2}{l|}{$\begin{array}{l}\text { Cumulative } \\
\text { Percentage }\end{array}$} \\
\hline Sponsored & 149 & 24,7 & 24,7 & 24,7 \\
\hline Non Sponsored & 455 & 75,3 & 75,3 & 100,0 \\
\hline Total & 604 & 100,0 & 100,0 & \\
\hline
\end{tabular}

According to Table 5, as a result of the content analysis, during the quarantine period $24.7 \%$ of the posts shared with sponsored posts, and $75.3 \%$ were not sponsored posts. In fact, this shows that commercial activities were decreasing during the quarantine period since influencers did not take sponsored posts.

Table 6. Status of Sponsored Post by Weeks

\begin{tabular}{|c|c|c|c|c|}
\hline \multirow[t]{2}{*}{ Valid } & & \multicolumn{3}{|c|}{ Status of Content } \\
\hline & & Sponsored & $\begin{array}{c}\text { Non } \\
\text { Sponsored }\end{array}$ & Total \\
\hline \multirow{11}{*}{$\begin{array}{l}\text { Week of the } \\
\text { Content }\end{array}$} & First Week (16-22 March) & 20 & 39 & 59 \\
\hline & Second Week (23-29 March) & 10 & 64 & 74 \\
\hline & Third Week (30 March 5 April) & 8 & 49 & 57 \\
\hline & Fourth Week (6-12 April) & 18 & 40 & 58 \\
\hline & Fifth Week (13-19 April) & 4 & 49 & 53 \\
\hline & Sixth Week (20-26 April) & 3 & 40 & 43 \\
\hline & Seventh Week (27 April-3 May) & 14 & 55 & 69 \\
\hline & Eight Week (4-10 May) & 21 & 41 & 62 \\
\hline & Ninth Week (11-17 May) & 24 & 38 & 62 \\
\hline & Tenth (18-24 May) & 21 & 28 & 49 \\
\hline & Eleventh Week (25-31 May) & 6 & 12 & 18 \\
\hline Total & & 149 & 455 & 604 \\
\hline
\end{tabular}

According to Table 6, the most sponsored posts belong to the $9^{\text {th }}$ week $(n=24)$ and the least sponsored posts belong to the $6^{\text {th }}$ week $(n=3)$. In general, it was found that sponsored posts were concentrated in the first week $(n=20)$, 8 th week $(n=21)$, 9th week $(n=24)$ and $10^{\text {th }}$ week $(n=21)$. Brand-influencer collaborations were planed weeks ahead. Therefore, it can be said that sponsored posts were mostly concentrated in the first week. However, there was a decrease in sponsored posts between the $2^{\text {nd }}$ and $7^{\text {th }}$ weeks. This situation can be explained by the economic uncertainty arising in the pandemic period. 
Table 7. Use of Hashtags

\begin{tabular}{|c|c|c|c|c|}
\hline Hashtags & Frequency & Percentage & \begin{tabular}{|l|} 
Valid \\
Percentage \\
\end{tabular} & $\begin{array}{l}\text { Cumulative } \\
\text { Percentage }\end{array}$ \\
\hline no hashtag & 564 & 93,4 & 93,4 & 93,4 \\
\hline 1 mayıs & 1 & 2 & 2 & 93,5 \\
\hline $\begin{array}{l}\text { 1mayısiçiveemekçibayramıkutluo } \\
\text { Isun }\end{array}$ & 1 & 2 & 2 & 93,7 \\
\hline 23nisan & 2 & 3 &, 3 & 94,0 \\
\hline $\begin{array}{l}\text { 23nisan 23nisanulusalegemenlikve } \\
\text { çocukbayramı }\end{array}$ & 1 & 2 & 2 & 94,2 \\
\hline $\begin{array}{l}\text { 23nisan 23nisanulusalegemenli } \\
\text { kveçocukbayramı evdekaltürkive } \\
\text { evdekal }\end{array}$ & 1 &, 2 &, 2 & 94,4 \\
\hline annelergünü & 1 & 2 & 2 & 94,5 \\
\hline corona & 1 & 2 & 2 & 94,7 \\
\hline $\begin{array}{l}\text { dünyatiyatrolargünü } \\
\text { dünyatiyatrogünü }\end{array}$ & 1 & 2 & 2 & 94,9 \\
\hline evdekal & 3 &, 5 &, 5 & 95,4 \\
\hline evdekal evdekaltürkiye & 1 & 2 & 2 & 95,5 \\
\hline evdekal evdekaltürkiye & 10 & 1,7 & 1,7 & 97,2 \\
\hline $\begin{array}{l}\text { evdekal evdekaltürkive } \\
\text { hayırlıramazanlar }\end{array}$ & 1 & 2 & 2 & 97,4 \\
\hline $\begin{array}{l}\text { evdekal evdekaltürkiye stayhome } \\
\text { staysafe }\end{array}$ & 1 & 2 & 2 & 97,5 \\
\hline evdekaltürkive & 2 & 3 &, 3 & 97,8 \\
\hline evdeyiz Godiva harikakareler & 1 & 2 & 2 & 98,0 \\
\hline $\begin{array}{l}\text { evindekaltürkiye evdekal } \\
\text { evdekaltürkiye }\end{array}$ & 1 & 2 & 2 & 98,2 \\
\hline HazzıBoldYașa & 1 & 2 & 2 & 98,3 \\
\hline hurafeteyze evdekal & 1 & 2 &, 2 & 98,5 \\
\hline iyibayramlar & 1 & 2 &, 2 & 98,7 \\
\hline iyigeceler & 1 &, 2 &, 2 & 98,8 \\
\hline lohusayımfarkındayım & 1 & 2 & .2 & 99,0 \\
\hline pinç babalatv & 2 & 3 &, 3 & 99,3 \\
\hline pișiğibeklemeönle & 1 &, 2 &, 2 & 99,5 \\
\hline quarentinepillowchallenge & 1 & 2 & 2 & 99,7 \\
\hline tb & 1 & 2 & .2 & 99,8 \\
\hline $\begin{array}{l}\text { twins smashcake oneage } \\
\text { firstbirthday }\end{array}$ & 1 &, 2 &, 2 & 100,0 \\
\hline Total & 604 & 100,0 & 100,0 & \\
\hline
\end{tabular}


According to Table 7, 93.4\% of the posts were made without using any hashtags, and only $6.6 \%$ of the posts were shared with the hashtags. Also, it can be concluded that not every hashtag used is related to COVID-19. Influencers also used hashtags related to some special days for Turkey, such as \#23nisan, (23 April) \#1mayis (1 May) or they used hashtags such as \#iyigeceler (good night) in their statements under the posts. The number of hashtags used for the pandemic was only 8 and the most used hashtag was \# evdekaltürkiye (stay at home Turkey) ( $n=6)$. It seems likely that the success of promoting specific hashtag content may differ for different celebrities.

Table 8. Type of Visuals

\begin{tabular}{|l|r|r|l|r|}
\hline $\begin{array}{l}\text { Visual } \\
\text { Typologies }\end{array}$ & Frequency & Percentage & \multicolumn{1}{l|}{$\begin{array}{l}\text { Valid } \\
\text { Percentage }\end{array}$} & $\begin{array}{l}\text { Cumulative } \\
\text { Percentage }\end{array}$ \\
\hline Photo & 328 & 54,3 & 54,3 & 54,3 \\
\hline Video & 250 & 41,4 & 41,4 & 95,7 \\
\hline IG Video & 23 & 3,8 & 3,8 & 99,5 \\
\hline Others & 3 &, 5 &, 5 & 100,0 \\
\hline & & & & \\
\hline
\end{tabular}

Findings of Table 8, due to the nature of the Instagram, $54.3 \%$ of the contents were shared in the photography style. This rate was followed by video with $41.4 \%$, IGTV with $3.8 \%$, and others with $0.5 \%$.

Table 9. Type of Message Tone

\begin{tabular}{|l|r|r|r|r|}
\hline Valid & Frequency & Percentage & Valid Percentage & $\begin{array}{l}\text { Cumulative } \\
\text { Percentage }\end{array}$ \\
\hline Sincere & 134 & 22,2 & 22,2 & 22,2 \\
\hline Humorous & 293 & 48,5 & 48,5 & 70,7 \\
\hline Critical & 5 &, 8 &, 8 & 71,5 \\
\hline Informative & 121 & 20,0 & 20,0 & 91,6 \\
\hline No text & 51 & 8,4 & 8,4 & 100,0 \\
\hline Total & 604 & 100,0 & 100,0 & \\
\hline
\end{tabular}

It was determined that the most used tone was humorous with $48.5 \%$. This rate was followed by a sincere tone with $22.2 \%$, an informative tone with $20 \%$ and a critical tone with $0.8 \%$. 
Table 10. Status of Places

\begin{tabular}{|l|r|r|r|}
\hline Valid & Frequency & Percentage & Valid Percentage \\
\hline Indoor & 507 & 83,9 & 83,9 \\
\hline Outdoor & 71 & 11,8 & 11,8 \\
\hline Other (no location infographic, music etc) & 26 & 4,3 & 4,3 \\
\hline Total & 604 & 100,0 & 100,0 \\
\hline
\end{tabular}

According to Table 10, the analysis showed that $83.9 \%$ of the posts shared during the quarantine period were posted from the indoors and $11.8 \%$ were posted from the outdoors. It was observed that the influencers shared particular spaces of their houses, such as gardens, poolsides, basketball courts, even if they were at home. Status information were examined as outdoor places.

Table 11. Post Topics

\begin{tabular}{|l|l|l|l|l|}
\hline Valid & Frequency & Percentage & $\begin{array}{l}\text { Valid } \\
\text { Percentage }\end{array}$ & $\begin{array}{l}\text { Cumulative } \\
\text { Percentage }\end{array}$ \\
\hline Cook & 56 & 9,3 & 9,3 & 9,3 \\
\hline Sports/Health & 19 & 3,1 & 3,1 & 12,4 \\
\hline Hobbies (book,film,music,puzzle etc) & 27 & 4,5 & 4,5 & 16,9 \\
\hline Online Shopping & 21 & 3,5 & 3,5 & 33,3 \\
\hline Advertisement & 109 & 18,0 & 18,0 & 51,3 \\
\hline Slice of Life (Life Style) & 221 & 36,6 & 36,6 & 87,9 \\
\hline TB (Throw Back) & 19 & 3,1 & 3,1 & 91,1 \\
\hline Social Responsibility & 3 &, 5 &, 5 & 91,6 \\
\hline YouTube Channel Annunciation & 51 & 8,4 & 8,4 & 100,0 \\
\hline Other & 78 & 12,9 & 12,9 & 29,8 \\
\hline Total & 604 & 100,0 & 100,0 & 100,0 \\
\hline
\end{tabular}

Findings of Table 11, among their posts, many topics were found respectively. The most topic that influencers have shared is the "lifestyle" topic $(36.6 \%)$, followed by $18 \%$ for advertisement, $9.3 \%$ for food, $8.4 \%$ for vlog announcements, $4.5 \%$ for hobby, 3.5\% for online shopping, and $3.1 \%$ for TB (throwback) and for $3.1 \%$ health and sports topics. 
Table 12. Offering Values

\begin{tabular}{|l|l|r|r|l|r|}
\hline Valid & Frequency & Percentage & $\begin{array}{l}\text { Valid } \\
\text { Percentage }\end{array}$ & $\begin{array}{l}\text { Cumulative } \\
\text { Percentage }\end{array}$ \\
\hline & Entertainment & 246 & 40,7 & 40,7 & 40,7 \\
\hline & Advice & 199 & 32,9 & 32,9 & 73,7 \\
\hline & Social & 3 &, 5 &, 5 & 74,2 \\
& Responsibility & & & & \\
\hline & Self -Expression & 21 & 3,5 & 3,5 & 77,6 \\
\hline & Inspring & 26 & 4,3 & 4,3 & 82,0 \\
\hline & Other & 109 & 18,0 & 18,0 & 100,0 \\
\hline & Total & 604 & 100,0 & 100,0 & \\
\hline
\end{tabular}

Influencers' most recommended values were entertainment value with $40.7 \%$, advice with $32.9 \%$, other with $18 \%$, inspiration with $4.3 \%$, self-expression with $3.5 \%$ and social responsibility with $0.5 \%$ respectively. In fact, this situation coincides with what they actually do. Because for many, their reason for being on Instagram is to entertain people. This is why research findings have supported this.

Table 13. Assumed Roles

\begin{tabular}{|l|r|l|r|}
\hline Valid & Frequency & Percentage & \multicolumn{1}{|l|}{ Valid Percentage } \\
\hline Entertainer & 210 & 34,8 & 34,8 \\
\hline Informer & 104 & 17,2 & 17,2 \\
\hline Economy Booster & 129 & 21,4 & 21,4 \\
\hline Fund Raiser & 4 &, 7 &, 7 \\
\hline Other & 157 & 26,0 & 26,0 \\
\hline Total & 604 & 100,0 & 100,0 \\
\hline
\end{tabular}

According to the findings, when compared to other roles, influencers adopted the entertainer role the most (with 34.8\%). This was followed by $26 \%$ with "other", 17.2\% with "informer", 21.4\% "economy booster" and 0.7\% "fundraising".

\section{Discussion and Conclusion}

Beyond the content of the Covid-19 messages alone, who communicates the message should be one of the most important factors in influencing the publics (Austin 1962). Celebrities have been shown to exert a strong influence on public opinion at large (Jackson 2018; Jackson and Darrow 2005), including opinions about health and well-being (Beck et.al. 2014). “Today, influencer 
relations have become one of the key components of organizations' communication mix." This study contributes to the development of pandemic communication in Turkey regarding the effectiveness of influencers as celebrities in communicating public health messaging during the COVID-19 pandemic. The findings presented here can help both governments and brands creating effective strategies for communicating for the COVID-19 crisis.

While it is possible that celebrities can bring increased awareness to health crises (Beck et. al. 2014), this awareness may not be associated with raised public understanding of related risks and cure (Kosenko et. al. 2016). Governments today, should start compiling a list of influencers as spokespersons for pandemic communication. The findings thus serve as a reminder to governments and companies not to underestimate their influencers power to inform and persuade. From the marketing perspective, findings show that Instagram is enabling influencers to market products and services through their profiles. They have become more than just a distribution channel, and also at-home creator for the broader communication mix in lockdowns. "Trends Report: The Impact of Coronavirus on Influencer Marketing reveals that, due to the coronavirus outbreak, influencers are actively seeking out video for many parts of their lives, including education, fitness, socializing, and wellness"' (Obviously 2020).

Findings showed that they were receiving fewer collaboration offers from brands due to COVID-19, while at the same time there was a decline in engagement rates. Francisco et al. $(2021,30)$ state that during the pandemic, many brands have had to adapt their marketing strategies to include masking and social distancing. There are more contact between brands and customers on social media platforms has been possible throughout this time period.

Surprisingly, findings revealed that influencers could not show any remarkable collaborations with brands during COVID-19 lockdowns. Brands may become creative with how they invite consumers into their digital world, without leaving the safety of their homes. While social distancing remains, collaborating with influencers to understand how to bring brand experiences into the homes of their followers will create closer connections between consumers and brands. When designing communication experiences at-home with influencers, it is recommended to the brands that rather than a rapid or simple post about a brand, they should use the lockdown to create long hour consumer experiences, such as live streams, demonstrations, virtual product experiences, etc. (Gilliland 2020). Brands need to find ways to be distinct. In- 
fluencers can be a perfect channel solution since they can use their personality and inbound the communication traffic.

Although individuals have uncertainty about their routine shopping habits during the quarantine period, they gained new shopping habits such as more online shopping and online payment or virtual payment systems. Brands which paid attention to the new consumer behaviors during the lockdowns have transformed their communication and transactions for this new period. It was observed that they have tried to integrate their communication efforts into lockdowns. Of course, it doesn't mean that brands should not establish their strategies based purely on the digital community, but also consider how the online presence can empower the offline community. Likewise, according to another research counducted by Mason et al. (2021, 13), given that COVID-19 appears to be encouraging consumers to engage in more online consumer behavior, social media's global significance is anticipated to grow.

The results of this study should be considered in the light of its limitations. The study was conducted only on Instagram with only ten microinfluencers that indicates the limitations of this study. There is also a time constraint. This study only covers a certain period of time. Future research should extend the study to other celebrities from different social spheres, such as music, TV show, movie, art and sport. Finally, as findings cannot determine the long-term effects, future research should replicate these results at different waves or the stages of the pandemic. 


\section{References}

Abidin, Crystal and Ots Marts. 2016. “Influencers Tell All? Unravelling Authenticity and Credibility in a Brand Scandal." In Blurring the Lines, edited by Maria Edström, Andrew, T. Kenyon and Eva-Maria Svensson, 151-163. Göteborg: Nordicom Press.

https://www.diva-portal.org/smash/get/diva2:1051578/FULLTEXT01. pdf\# page $=155$.

Abraham, Thomas. 2011. "Lessons from The Pandemic: The Need for New Tools for Risk and Outbreak Communication." Emerging Health Threats Journal 4 (1): 1-4. 10.3402 / ehtj.v4i0.7160.

Acar, Arman. 2020. “United Ad 2020 Influencer Marketing Trendleri.” Last modified 15 January 2020. Accessed date 3 December 2021 https: / / unite.ad/blog/2020-instagram-influencer-marketing-trendleri /

Adba Analytics. 2020. “Koronavirüs Sosyal Medyaya Nasıl Yansıdı?” Last modified April 21, 2020. Accessed date 3 December 2021

https: / / www.adbaanalytics.com/inova portfolio/ covid-19-dijital-mecralaranalizi/

Akyazı, Ayşenur. 2019. “Mahremiyetin Dönüşümü: Ünlülerin Instagram Paylaşımları Üzerine Bir Araştırma" Gaziantep University Journal of Social Sciences 18 (1): 197-216.

https:// doi.org/10.21547/jss.431086.

Alatas, Vivi, Arun G. Chandrasekhar, Markus Mobius, Benjamin A. Olken and Cindy Paladines. 2019. "When Celebrities Speak: A Nationwide Twitter Experiment Promoting Vaccination In Indonesia." Nber Working Paper Series, Accessed, September 3, 2021. Accessed date 3 December 2021 https:/ / www.nber.org/system/files/working_papers/w25589/w25589.pdf

Aslan, Alev and Derya Ünlü Gül. 2016. “Instagram Fenomenleri ve Reklam İlişkisi: Instagram Fenomenlerinin Gözünden Bir Değerlendirme” Maltepe Üniversitesi İletişim Fakültesi Dergisi 3 (2): 41-65.

Austin, John Langshaw. 1962. How to Do Things with Words. Oxford: Oxford University Press.

Baki, Adnan and Tuba Gökçek. 2012. "Karma Yöntem Araştırmalarına Genel Bir Bakış." Elektronik Sosyal Bilimler Dergisi 11(42): 1-21. ISSN: 1304-0278 / 13040278 .

Baltacı, Ali. 2019. "Nitel Araştırma Süreci: Nitel Bir Araştırma Nasıl Yapılır?" Ahi Evran Üniversitesi Sosyal Bilimler Enstitüsü Dergisi 5 (2): 368-388. $\underline{10.31592 / \text { aeusbed.598299. }}$. 
Ballantine, W. Paul and S. A. Brett Martin. 2005. "Forming Parasocial Relationships in Online Communities" Advances in Consumer Research (32): 197-201.

BCU Digital. 2021. “Micro-Influencer ve Macro Influencer Nedir?" Last modified September, 3, 2021. Accessed date 3 December 2021 https: / www.bcudigital.com/micro-influencer-ve-macro-influencer-nedir/.

Beck, S. Christina. 2014. "Blurring Personal Health and Public Priorities: An Analysis of Celebrity Health Narratives in the Public Sphere". Health Communication 29 (3): 244-256.

https:/ / doi.org/10.1080/10410236.2012.741668 PMID: 23548050.

Berne-Manero, Carmen and Mercedes Marzo-Navarro. 2020. “Exploring How Influencer and Relationship Marketing Serve Corporate Sustainability" Sustainability 12 (4392): 1-19.

$\underline{10.3390 / \text { su12114392. }}$.

Bishop, Katie. 2020. The Pandemic and The Influencer: Will the Lifestyle Survive Coronavirus?" The Guardian, May 2, 2020.

https:// www.theguardian.com/media/2020/may/02/influencerscoronavirus-future-income-marketing-lifestyle.

Boerman, C. Sophie. 2020. “The Effects of Standardized Instagram Diclosure For Micro And Meso Influencers" Computers in Human Behavior (103): 199-207. https:// doi.org/10.1016/j.chb.2019.09.015.

Boom Social. 2021. “Instagram | Fenomenler Sektörü Hesapları.” Last modified February 4, 2021. Accessed date 3 December 2021 https:/ / www.boomsocial.com/instagram/UlkeSektor/turkey/fenomenler

Borén, Thomas. 2020. “Governments and Social Media Influencers in Times of Crisis", M.A. Thesis., Aalborg University. https:/ / projekter.aau.dk/projekter/en/studentthesis/governmentsand-social-media-influencers-in-times-of-crisis(e325777f-45f6-4d61-8777$\underline{15 \mathrm{be} 0 \mathrm{a} 80563 \mathrm{c}) \cdot \mathrm{html}}$.

Brown, J. William and Micheal D. Basil. 1995. “Media Celebrities and Public Health: Responses to 'Magic' Johnson's HIV Disclosure and Its Impact on AIDS Risk And High-Risk Behaviors. Health Communication, 7 (4): 345-370. $10.1207 / \mathrm{s} 15327027 \mathrm{hc} 0704$ 4C.

Brown, J. William, Micheal D. Basil and Mihai C. Bocarnea. 2003. "The Influence of Famous Athletes on Health Beliefs and Practices: Mark McGwire, Child Abuse Prevention, And Androstenedione" Journal of Health Communication, (8): 41-57. $\underline{10.1080 / 10810730305733 .}$. 
Brown, J. William and Benson P. Fraser. 2004. "Celebrity Idenfication." In Entertainment-Education: and Social Change: History, Research, and Practice, edited by Arvind Singhal, Micheal J. Cody, Everett M Rogers, Miguel Sabido, 97-111. New Jersey, Lawrence Erlbaum Associates Press.

Campaign Türkiye. 2020. “Trendyol'dan “Süper İndirim Günleri’ne Özel Reklam Filmi Serisi." Last modified November 10, 2020. Accessed January 282021. https:/ / www.campaigntr.com/trendyoldan-super-indirim-gunlerine-ozelreklam-filmi-serisi/

Cheney, George. 1983. "The Rhetoric of Identification And The Study of Organizational Communication. Quarterly Journal of Speech., 69 (2): 143-158.

Christodoulaki, Almperta. 2018. "The Effects of Micro vs Macro Influencers on Brand Awareness, Brand Attitude, and Purchase Intention, and the Moderating Role of Advertising Appeals." M.A. Thesis, University of Amsterdam.

https: / / docplayer.net/142524584-Running-head-the-effects-of-micro-vsmacro-influencers-1.html.

CNN Turk. 2020. “İşte Koronavirüse Karşı Gece Gündüz Demeden Çalışan 26 Bilim Kurulu Üyesi” Last modified March 27 2020, Accessed January 272021 https:// www.cnnturk.com/turkiye/iste-koronaviruse-karsi-gece-gunduzdemeden-calisan-26-bilim-kurulu-uyesi.

Coelho, Rita Magalhães Moreira. 2019. “The Influencer Marketing :The Impact of the Number of Followers on Influencer's Likability for Young Instagram Users." M.A. Thesis, The Catholic University of Portugal. https:// repositorio.ucp.pt/handle/10400.14/28568.

Cretor Den, 2019. “2019 Genel Bakış”, Accessed Februrary 6, 2021.

https: / / creatorden.com/2019da-influencer-marketingde-neler-oldu /

Daily Sabah. 2020. "Turkey to Shut Down Social Spaces: Cafes, Theaters, Gyms Vacated Amid Virus Fears." Last modified March 16, 2020. Accessed January $28,2021$.

https: / / www.dailysabah.com/turkey/turkey-to-shut-down-social-spacescafes-theaters-gyms-vacated-amid-virus-fears/news.

Dhanesh, Ganga and Gaelle Duthler. 2019. "Relationship Management Through Social Media Influencers: Effects of Followers' Awareness Of Paid Endorsement." Public Relations Review 45 (3): 1-13. https: / / doi.org/10.1016/j.pubrev.2019.03.002.

Donald, Horton and Richard Wohl. 1956. "Mass Communication and Para-Social Interaction. Psychiatry: Journal for the Study of Interpersonal Processes 19(3): 215-229. $\underline{10.1080 / 00332747.1956 .11023049}$ 
Ducharme, Jamie. 2020. "How to Soothe Your 'Re-Entry Anxiety' As COVID-19 Lockdowns Lift." Time, June, 11, 2020. https: / time.com/5850143/ covid-19-re-entry-anxiety/.

Elli, Diza Maria. 2017. “The Phenomenon and Rise of Influencer Marketing and How it Affects Customer Opinion and Helps or Damages Brands." M.A. Thesis, The International Hellenic University. https://lk.tc/ass8x.

Elmacıoğlu, Lale. 2020. “Koronavirüs Tecridi Sosyal Medya Influencerlarını Nasıl Etkiledi?" Independent Turkey, March 22, 2020. https: / / lk.tc/hwtau.

Francisco, Evelina, Nadira Fardos, Aakash Bhatt and Gulhan Bizel. 2021. "Impact of the COVID-19 Pandemic on Instagram and Influencer Marketing." International Journal of Marketing Studies 13 (2): 20-35. $\underline{10.5539 / \text { ijms.v13n2p20 }}$

Fraser, P. Benson and William J. Brown. 2002. “Media, Celebrities, and Social Influence: Identification with Elvis Presley." Mass Communication \& Society 5 (2): 183-206. https:// doi.org/10.1207/S15327825MCS0502 5.

Fuchs, Christian. 2020. "Everyday Life and Everyday Communication in Coronavirus Capitalism." TripleC 18 (1): 375-399. https:/ / doi.org/10.31269/triplec.v18i1.1167.

Gilliland, Nikki. 2020. "How the Influencer Marketing Industry Is Adapting to Coronavirus." Econsultancy, April 2, 2020. https: / / econsultancy.com/how-the-influencer-marketing-industry-isadapting-to-coronavirus $/$.

Guruge, Miyuru C. B. 2018. "Comparison Between Attributes Related to Celebrity Endorsement and Social Media Influencer Marketing: a Conceptual Review." Sri Lanka Journal of Marketing 4 (1):17-37. http:/ / fcms.kln.ac.lk/dep/dmm/images/SLJM/4-1/M.C.B.-Guruge--Online-Publish.pdf.

Haleem, Abid, Mohd Javaid and Raju Vaishya. 2018. "Effects of COVID-19 Pandemic in Daily Life." Current Medicine Research and Practice 10 (2): 78-79. https:/ / doi.org/10.1016/j.cmrp.2020.03.011

Hartmann, Tilo and Charlotte Goldhoorn. 2011. “Horton and Wohl Revisited: Exploring Viewers' Experience of Parasocial Interaction." Journal of Communication (61): 1104-1121. 10.1111/j.1460-2466.2011.01595.x. 
Hughes,Christian, Vanitha Swaminathan and Gillian Brooks. 2019. “Driving Brand Engagement Through Online Social Influencers: an Empirical Investigation of Sponsored Blogging Campaigns." Journal of Marketing 83 (5): 1-9.

Hurd, Nora. 2018. “Instagram Users' Meaning Construction Through MicroInfluencer-Generated Content." M.A. Thesis., Tampere University. https://trepo.tuni.fi/handle/10024/117332.

Jackson, J. David. 2018. “The Effects of Celebrity Endorsements of Ideas and Presidential Candidates." Journal of Political Marketing 17 (4): 301-321. https: / / doi.org/10.1080/15377857.2018.1501530.

Jackson, David and Thomas Darrow. 2005. “The Influence of Celebrity Endorsements on Young Adults' Political Opinions." The International Journal of Press/Politics 10 (3): 80-98.

https:// doi.org/10.1177/1081180X05279278.

Jin, Venus, Aziz Muqaddam and Ehri Ryu. 2019. "Instafamous and Social

MediaInfluencer Marketing." Marketing Intelligence \& Planning (37) 5: 567-579. https:// doi.org/10.1108/MIP-09-2018-0375.

Jones, C. S. Louise Waters, Omnia Holland, John Bevins and Don Iverson, 2010. "Developing pandemic communication strategies: Preparation without panic." Journal of Business Research (63) :126-132. https:// doi.org/10.1016/j.jbusres.2009.02.009.

Karanikolova, Monika. 2019. “Fashion Influencers Decoded: The Role of Social Media Influencers In Luxury Fashion Houses Development, Marketing and PR Strategies." Master Thesis., Sapienza University.

Kay, Samantha, Rory Mulcahy and Joy Parkinson. 2020. “When Less Is More: The Impact of Macro and Micro Social Media Influencers' Disclosure." Journal of Marketing Management 36 (3-4): 239-278.

$\underline{10.1080 / 0267257 X .2020 .1718740 .}$.

Kırık, Ali Murat and Vahdet Özkoçak. 2020. “Yeni Dünya Düzeni Bağlamında Sosyal Medya ve Yeni Koronavirüs (Covid19) Pandemisi." The Journal of Social Sciences 7 (45): 133-154.

$10.29228 /$ sobider.43146.

Kosenko, A. Kami, Andrew R. and Ryan Hurley. 2016. “Celebrity Influence and Identification: A Test of The Angelina Effect." Journal of Health Communication (21): 318-326. $\underline{10.1080 / 10810730.2015 .1064498 .}$.

Krippendorff, K. 2011. “Computing Krippendorff's Alpha-Reliability. The Basics of Communication Research." Cengage Learning. https:// www.polcomm.org/wp-content/ uploads/ICR01022012.pdf. 
Launch Metrics. 2020. The State of Influencer Marketing Report. Accessed September, 3, 2021.

https:/ / www.launchmetrics.com/landing/influencer-marketing-report-2020

Limaye, Jayant Rupali, Molly Sauer, Joseph Ali, Justin Bernstein, Brian Wahl, Anne Barnhill and Alain Labrique. 2020. "Building Trust While Influencing Online COVID-19 Content In The Social Media World." The Lancet Digital Health 2 (6): 277-278.

$\underline{10.1016 / \mathrm{s} 2589-7500(20) 30084-4}$.

Lin, Leesa, Rachel F. McCloud, Cabral A. Bigman and Kasisomayajula Viswanath. 2017. "Tuning in And Catching on? Examining the Relationship Between Pandemic Communication and Awareness and Knowledge of MERS in the USA." Journal of Public Health 39 (2): 282-289. $10.1093 /$ pubmed/fdw028.

Lin Chen-Hsin, Patrick F. Bruning and Hepsi Swarna. 2018. “Using Online Opinion Leaders to Promote The Hedonic and Utilitarian Value of Products and Services." Business Horizons 61 (3): 431-442. https:// doi.org/10.1016/j.bushor.2018.01.010.

Longstaff, H.P. and Sung-Un Yang. 2008. “Communication Management and Trust: Their Role in Building Resilience to "Surprises" Such as Natural Disasters, Pandemic Flu, And Terrorism." Ecology and Society 13 (1): 1-15.

Lorenz, Taylor. 2020. "Flight of the Influencers.", NY Times. Accessed date 3 December 2021 https://www.nytimes.com/2020/04/02/style/influencers-leave-new-yorkcoronavirus.html.

Lorimer, Rowland. 2002. "Mass Communication: Some Redefinitional Notes." Canadian Journal of Communication (27): 63-72. $\underline{10.22230 / \text { cjc. } 2002 \mathrm{v} 27 \mathrm{n} 1 \mathrm{a} 1272 .}$

Mahajan, Rajendra. 2015. "The Key Role of Communication Skills in the Life of Professionals." Journal of Humanities and Social Science 20 (12): 36-39. $10.9790 / 0837-201223639$.

Marketing Hub. 2019. "The State of Influencer Marketing 2019: Benchmark Report." Last modified 14 February, 2021. Accessed date 3 December 2021 https: / influencermarketinghub.com/influencer-marketing-2019-benchmarkreport/

Marketing Türkiye. 2020. “Koronavirüs Döneminde Sosyal Medya ve Influencer pazarlama çalışmaları arttı.". Accessed January 30, 2020.

https:/ / www.marketingturkiye.com.tr/haberler/pandemi-donemindesosyal-medya-ve-influencer-pazarlama-calismalari-artti/ 
Marra, Annachiara, Buonanno Pasquale, Vargas Maria, Iacovazzo Carmine, Ely Wesley Eugene, and Servillo Giuseppe. 2020. "How COVID-19 Pandemic Changed Our Communication with Families: Losing Nonverbal Cues." Critical Care 24 (297): 1-12. https: / / doi.org/10.1186/s13054-020-03035-w.

Mason, Andrew, John Narcum and Kevin Mason. 2021. “Social Media Marketing Gains Importance After Covid-19." Cogent Business \& Management 8 (1) :1-17.

McKernan, Bethan. 2020. “Turkey Announces Its First Case of Coronavirus." The Guardian. March 11, 2020. https: / / www.theguardian.com/world/2020/mar/11/turkey-announces-itsfirst-case-of-coronavirus.

Nguyen, Ha My. 2020. “The Impact of Influencer Marketing in Vietnamese Customer's Perceptions." Bachelor Thesis., Vaasan Ammattikorkeakoulu University of Applied Science. http: / / urn.fi/URN:NBN:fi:amk-202002021919

Nouri, Melody. 2018. “The Power of Influence: Traditional Celebrity vs Social Media Influencer." Advanced Writing: Pop Culture Intersections, (32): 1-20. https: / scholarcommons.scu.edu/engl 176/32/

Obviously. 2020. "The Impact of Coronavirus on Influencer Marketing" Accessed June 2021. https://static1.squarespace.com/static/5b1f2ba0b40b9d244893933e/t/5e8360 8cc927de74e8d5d298/1585668329525/Trends+Report+The+Impact+of+Coron avirus+on+Influencer+Marketing+Obviously.pdf

Ogilvy Agency. 2020. "Influencing is Our New Reality", Accessed February 6, 2021. https://www.ogilvy.com/sites/g/files/dhpsjz106/files/pdfdocuments / Conversations $\% 20$ that $\% 20$ Matter $\% 20-\%$ 20Influencing $\% 20$ our $\% 20 \mathrm{New} \% 20$ $\underline{\text { Reality.pdf }}$

Özpınar, Baygüş Şaha and Gülşah Aydın. 2020. “Kriz İletişiminde İnfografik Kullanımı: Covid 19 Pandemi Sürecinde İnfografikler Üzerine Bir İnceleme." İstanbul Ticaret Üniversitesi Sosyal Bilimler Dergisi (Covid 19 Special Issue): 240261.

Pan American Health Organization. 2009. “Creating a Communication Strategy for Pandemic Influenza". Accessed date 3 December 2021 https: / / www.paho.org/hq/dmdocuments/2010/PAHO_CommStrategy Eng.pdf

Plus. 2019. "Denebunu 2019 Ödülleri Sahiplerini Buldu". Accessed date 3 December 2021

https: / / www.plusdergisi.com/denebunu-2019-odulleri-sahiplerini-buldu/ 
Podschuweit, Nicole. 2017. "Interpersonal Communication: Media Influence on." The International Encyclopedia of Media Effects, 1-12.

$\underline{10.1002 / 9781118783764 . w b i e m e 0137}$

Potter, J. M. 2009. Arguing for a Genaral Framework for Mass Media Scholarship. California: SAGE Public.

Reitere, Sarma. 2020. "What Social Media Platforms are Doing to Help During the Coronavirus." Accessed January 312021.

https: / / www.socialbakers.com/blog/social-media-platforms-duringcoronavirus

Romana, Andò. 2016. “The Ordinary Celebrity: Italian Young Vloggers and the Definition Of Girlhood." Film, Fashion E Consumption 5 (1): 123-139. $\underline{10.1386 / \text { ffc.5.1.123 } 1}$

Sarıtaş, Ayşe. 2018. “Sosyal Medya Reklamlarında Fenomen Kullanımı ve Reklam İzleme Tercihi." The Journal of International Scientific Researches 3 (4): 62-74. https:// doi.org/10.23834/isrjournal.473169.

Shiromani, Gupta and Rachna Mahajan. 2019. “Role of Micro-Influencers in Affecting Behavioural Intentions." International Journal of Recent Technology and Engineering 8 (5): 189-192. $\underline{10.35940 / \text { ijrte.D1045.1284S519. }}$

Social Bakers. 2020. "State of Influencer Marketing Report: Effects of Coronavirus". Accessed January 312021. https://www.socialbakers.com/blog/influencer-marketing-report

Solak, Bahadır Burak. 2016. “Televizyon Reklamlarında Ünlü Kullanımının Satın Alma Davranışı Üzerine Etkisi: Akdeniz Üniversitesi İletişim Fakültesi Öğrencilerine Yönelik Bir Araştırma." Gumushane University E-Journal of Faculty of Communication 4 (1): 253-178. https:// doi.org/10.19145/guifd.84587.

Statista. 2020a. "Number and Change of Coronavirus (COVID-19) Cases and Deaths Among the Most Impacted Countries Worldwide as of February 1, 2021." Accessed September 3, 2021. https: / / www.statista.com/statistics / 1105264/ coronavirus-covid-19-casesmost-affected-countries-worldwide/

Statista. 2020b. "Share of Adults in the United States Who Have Used Digital Communication Services to Connect with Others During the Coronavirus Outbreak as of March 2020." Accessed date 3 December 2021 https://www.statista.com/statistics/1108828/usa-coronavirus-digitalcommunications-usage $/$. 
Stemler, Steve. 2001. "An Overview of Content Analysis." Practical Assessment, Research, and Evaluation: 7 (17): 1-6. https:// doi.org/10.7275/z6fm-2e34.

Suciu, Peter. 2020. "Social Media Health Influencers Continue to Be Resource During Covid-19 Pandemic." Forbes, Jul 16, 2020.

https: / / www.forbes.com/sites/petersuciu/2020/07/16/socialmedia-health-influencers-continue-to-be-resource-during-covid-19pandemic/\#1b7fa93d1462

Thomas, Richard. 2006. Health Communication. Berlin: Springer Press.

United. Ad. 2020. “COVID-19 X Influencer Marketing”, Accessed 27 January 2021, https: / / unite.ad/files / Covid-19XInfluencerMarketing.pdf

We Are Social. 2020. "2020 Türkiye İnternet Kullanımı ve Sosyal Medya İstatistikleri”. Accessed date 3 December 2021 https: / / dijilopedi.com/2020-turkiye-internet-kullanimi-ve-sosyal-medyaistatistikleri/.

Wen, Nainan. 2017. “Celebrity Influence and Young People's Attitudes Toward Cosmetic Surgery in Singapore: The Role of Parasocial Relationships And Identification." International Journal of Communication (11): 1234-1252.

Wen, Tiffanie. 2020. "Our Relationship with Voice and Video Chat is Changing in the Covid-19 Era. How Should Those Who Dislike Phone and Video Chat Handle the Influx of Calls?." BBC, April 9, 2020.

https: / / www.bbc.com/worklife/article/20200408-coronavirus-howlockdown-helps-those-who-fear-the-phone.

WHO. "Archived: WHO Timeline-COVID-19". Accessed Nov 4, 2021. https:// www.who.int/news/item/27-04-2020-who-timeline---covid-19

Vaughan, Elaine and Timothy Tinker. 2009. "Effective Health Risk Communication About Pandemic Influenza for Vulnerable Populations." American Journal of Public Health 2 (99): 323-334.

10.2105/AJPH.2009.162537

Velentaz, John and Georgia Broni. 2014. "Communication Cycle: Definition, Process, Models and Examples." In Recent Advances in Financial Planning and Product Development. Edited by Josef Börcsök, Micheal Schwarz, İstanbul: WSEAS Press, 117-131.

Yaylagül, Şinasi. 2017. “Sosyal Medya Fenomenlerine Bağlanmışlı̆̆ın Belirlenmesi: Yükseköğretim Öğrencileri Üzerine Bir Uygulama." Adnan Menderes University, Journal of Institute of Social Sciences 4 (3): 219-235.

https:// doi.org/10.30803/adusobed.349934. 
Yavuz, Kübra. 2020. "Effects of COVID 19 Pandemic on the Future of Social Policy." The Journal of Social Sciences 7 (45): 181-193.

http://dx.doi.org/10.29228/SOBIDER.42843.

Youtube. 2021. “Head\&Shoulders Reklam Çekimi Vlog. (Kaç Saat Sürdü İnanamadım)" filmed at January 2021 at YouTube, İstanbul. https: / / www.youtube.com/watch?v=cg0aqMSTyyQ\&feature=youtu.be.

Zikmund, William, Barry J. Babin, B. J Jon C. Carr and Mitch Griffin. 2003. “Research Methods." Health Economics Research Method (2). https://lk.tc/YJhjU. 